\title{
Motivational Factors for School-Based Teacher Learning: Turkish Pre-Service Teachers' Experiences and Expectations
}

\author{
Ali Eryllmaz ${ }^{1}$ \\ Eskişehir Osmangazi University
}

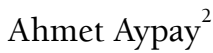 \\ Eskişehir Osmangazi University
}

\begin{abstract}
The purpose of this study is to describe the motivational factors of pre-service teachers' school-based learning. The study group comprised of 99 pre-service teachers in Eskişehir, Turkey. 53 of them (19 males and 34 females) were history teachers; and 46 of them ( 25 males and 22 females) were mathematics pre-service teachers. Data was collected via an open ended form which includes questions concerning their experiences and expectations in school. The questions were meant to identify and investigate the motivational aspects that enhance pre-service teachers' school-based learning. A sentence-based content analysis method was used to analyze their responses. Analyses indicated that there were some motivational factors for schoolbased teacher learning: qualities of schools, mentors, students, classrooms, and other teachers, educational approaches, and intimate relationships. This qualitative information was then used to develop a model for motivational factors for school-based teacher learning. Findings also indicated that a holistic, practice-based approach should be used to facilitate school-based teacher learning.
\end{abstract}

Keywords

Motivational factors • School-based learning • Pre-service teacher

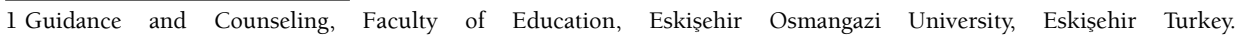
Email:erali76@hotmail.com

2 Correspondence to: Ahmet Aypay (PhD), Educational Administration, Faculty of Education, Eskişehir Osmangazi University, Eskişehir Turkey. Email:aypaya@gmail.com

Citation: Eryılmaz, A., \& Aypay, A. (2016). Motivational factors for school-based teacher learning: Turkish pre-service teachers' experiences and expectations. Educational Sciences: Theory \& Practice, 16, 357-373.
} 
Teaching practice has long been central for teacher learning. Pre-service teachers learn best when they develop their capabilities as teachers by controlling and testing their own experiences. Currently, the most important context where learning occurs is in school. Teachers in school should display consistency for engagement and motivation for learning to undergo a successful teaching process, personal development, and also be able to follow recent developments and improvements in education (FokkensBrunisma \& Canrinus, 2011). This process is of great importance for pre-service teachers. Most particularly, school-based teacher learning is an important cornerstone of the many developmental domains for pre-service teachers. Thus, it is important to know what factors are related to school-based learning for pre-service teachers. Schoolbased learning helps to make an effective teacher and is also important for a teacher's continued professional development (Hodkinson \& Hodkinson, 2005). Hence, studying the school-based learning of pre-service teachers and their expectations and experiences may contribute to improved pre-service teacher training.

Teacher learning is a significant component of the process of becoming a teacher. However, there are different approaches to teacher learning in literature (Flores, 2001). In general, teacher learning is considered within three perspectives: individual learning to teach, learning in school, and learning in a university setting (Korthagen, Loughran, \& Russell, 2006). Thus, school-based learning means learning in schools. The most important benifit of school-based learning is that it gives teachers a significant opportunity to learn by doing or by trial and error (Kwakman, 2003). Furthermore, it has long been known that school-based learning is essential to be an effective teacher, and also school-based learning produces many challenges and rewards (Cuenca, 2010). Moreover, teachers have considerable opportunities to learn from schools in their daily environment (Daniel \& Stallion, 1996).

Researchers examined school-based learning to understand "how teacher learning can be promoted?" (Hoekstra \& Korthagen, 2011). Motivational perspectives might help to answer this question. Motivation is considered the set of internal and external forces that initiate learning-related behavior, and determine its duration, intensity, form, and direction (Reeve, 1992). In educational settings, the subject of motivation has been considered part of mastery achievement-goal theory or performanceoriented goals (Turner \& Patrick, 2004), self-determination theory or intrinsicextrinsic motivation (Deci \& Ryan, 1985), and self-efficacy theory (Bandura, 1986). These studies and theories indirectly tend to focus on the subject of motivational factors for school-based teacher learning. Furthermore, some studies focus on teachers' motivation in terms of their motivation for becoming a teacher (Roness \& Smith, 2010), pre-service teachers' values and interest in the teaching profession (Fokkens-Brunisma \& Canrinus, 2011), teacher education program quality (Canrinus \& Fokkens-Bruinsma, 2014), teacher interest in teaching and dropout rates among 
student teachers (Trigwell \& Prosser, 1996). However, motivational factors for school-based teacher learning have not been investigated directly.

Teacher learning has been considered an important indicator of the professional development of teachers (Hoekstra \& Korthagen, 2011). Thus, recently teacher learning has been increasingly investigated in literature (Davey, 2013). Some countries such as England, USA and Australia have also invested in the development of teacher education programs (Willams, 2014). In order to understand the motivational factors behind school-based teacher learning, it is important to study pre-service teacher experiences and expectations concerning what goes on in schools. Furthermore, teacher feedback and appraisal make a significant contribution to develop teaching skills and learning within schools (Chait, 2010). Moreover, studies indicate that students and schools suffer when less qualified and ineffective teachers are employed (Okpala \& Ellis, 2005). Specifically, studies that focus on teacher education were generally more concerned with the relationship between theory and practice in Turkey. Studies that examine these relationships were more interested in what extent pre-service teachers educated in the faculties of education were able to transfer these skills in their teaching experiences (Simsel \& Yildirim, 2001; Uygun \& Akınc1, 2015). In other words, these studies do not investigate what pre-service teachers learn from their experiences in schools (school-based learning). What is generally not taken into account is the fact that pre-service teachers also obtain their experiences in school.

Consequently, teachers should update their knowledge of a subject in the light of developments in their field and pedagogy. To achieve these goals, pre-service teachers should have a higher motivation to learn. However, only a limited investigation of the motivational basis for school-based teacher learning has been done. Thus, the motivational factors should be investigated from the pre-service teachers' perspectives. Accordingly, the purpose of the present study is to investigate pre-service teachers' experiences and expectations about the motivational factors of school-based learning.

\section{Method}

\section{Research Design}

Among qualitative research methodologies, a phenomenological approach was used to describe the motivational factors of school-based learning. A phenomenological approach was used when an experience or phenomenon was described based on a certain group of individuals' experiences and expectations (Christensen, Johnson, \& Burke, 2015; Cresswell, 2007). According to Creswell (2007), phenomenological design focusus on the meaning of lived experiences among individuals. Data should be collected from individuals who experience the phenomenon under investigation. 
In this approach, researchers focus on important statements, sentences, themes, and integrated meanings.

In the current study, the phenomenon is motivational factors of school-based learning for pre-service teachers. Various studies define school-based learning differently. However, the definitions include some common aspects such as situated learning experiences, engagement in school settings, connecting theory, and practice (Daniel \& Stallion, 1996; Hodkinson \& Hodkinson, 2005; Hudson, 2010; Hudson \& Hudson, 2012; Korthagen et al., 2006). A general definition of school-based learning is a learning experience that provides an opportunity to develop teaching knowledge and skills in school settings (Grotenboer, 2005). Motivational factors are the set of internal and external forces that initiate learning-related behavior, and determine its duration, intensity, form, and direction (Reeve, 1992). As a result, the purpose of the present study is to describe the pre-service teachers' experiences and expectations of motivational factors in school-based learning.

Researchers argue teacher learning may be facilitated when motivational factors are investigated. Motivation for learning includes internal and external factors that facilitate or hamper learning (Hoekstra \& Korthagen, 2011; Reeve, 1992). From this perspective, this study focused on the pre-service teacher experiences and expectations. Motivational factors related to pre-service teachers' school-based learning were investigated in the context of their experiences in school.

\section{Data Analysis}

In phenomenological research, data analysis is conducted in three stages. The first stage includes determining significant phrases or sentences that are directly related to lived experiences. In the second stage, meanings are derived from significant sentences and then they are clustered into themes. Finally, results are integrated into an exhaustive description of the phenomenon (Creswell, 2007).

These three stages were taken into account in the analysis of data in the current study. Thus, the data analysis procedure was as follows: sentences were used as significant statements. Moreover, paragraphs were used to determine the relationships among the themes and exhaustive descriptions. Similarly, sentences and paragraphs were used as sampling units.

There are three steps in emergent themes. In the first one, two researchers independently reviewed the sentences and came up with two separate checklists based on them. Second, the two researchers compared sentences and paragraphs to reconcile the differences that emerged in the initial analysis. Third, the researchers used coding independently. Later, the researchers checked the agreement levels. The 
agreement levels were appropriate, inappropriate, and not applicable (Fraenkel \& Wallen, 1993; Haney, Russel, Gulek \& Fierros, 1998).

Accordingly, 132 sentences were recorded in response to the first question and 119 for the second question. In other words, significant statements were then grouped into themes, and the number of themes and sub-themes that explain variations in the data were reduced. Thereafter, different sentences of a similar construct were assigned under exhaustive descriptions.

The reliability of the study was examined in two ways. Firstly, two researchers independently coded the sentences using the same procedure. Secondly, two experts (an educational psychologist and a counsellor) participated in an inter-rater reliability process. For validity, the researchers used a member check with twenty eight students. Once the coding and process was completed, the results were presented to this group of students. They were asked whether they have any objections to these interpretations. Moreover, Shapiro and Markoff (1997) argued that if the results are related to other research results, then content analysis is valid. The findings were also compared with empirical and theoretical findings of other research (Ames, 1992; Bandura, 1986; Dembo \& Gibson, 1985; Flores, 2001; Ronfeldt, Reininger, \& Kwok, 2013; Stronge, 2007; Teitel, 2001). Moreover, two experts in English Language Teaching read independently for possible problems in translation from Turkish into English. Their comments were taken into account.

Additionally, the appropriateness of the sentences and themes was evaluated using a four Likert-type scale (strongly disagree, disagree, agree, and strongly agree) by two independent coders with $\mathrm{PhD}$ level qualifications, apart from the researchers in counseling psychology and educational psychology. As a result of their examination, 15 sentences for which there were disagreements were excluded from the themes. Inter-rater reliability was computed as 0.87 for sentences in the first question group, and 0.89 for sentences in the second question group. Lastly, in order to identify core processes and to help facilitate the development of models, supporting theory, significant statements, and themes were integrated into exhaustive descriptions. In this way, two relevant models were obtained.

Based on research results and consulting literature, two important hypothetical and research based models were developed in the current study. While constructing hypothetical models, three important sources need to be utilized. They are research results, theoretical explanations, and logical relationships (Kline, 2005). In addition to these criteria, the following criteria were utilized: paragraphs and consistency between researchers.

Two researchers independently read the paragraphs related to themes and exhaustive descriptions. In order to determine the relationship among dimensions in the two 
models, the two researchers compared model dimensions to reconcile the differences that emerged in the initial analysis. Later, the researchers constructed models independently. Consequently, the researchers finalized the model by working together.

\section{Participants}

In this study, purposive sampling methods were used. Purposive sampling allows the researcher to select some part of the universe. Another reason for selecting a purposive sampling is that it allows the researcher to select the most appropriate observation unit from the universe and to select a specific unit based on the theoretical knowledge and specific goals of the study (Fraenkel \& Wallen, 1993). According to Creswell (2007), purposive sampling provides participants to understand the research problem and phenomenon.

The participants of the study were pre-service teachers who were taking their practice courses in schools. One group from the sciences and one group from social sciences were selected. For inclusion criteria, enrollment in school practice was required. The initial study sample comprised of 103 pre-service teachers who were students at a state university in Turkey. Four of these students expressed dissatisfaction with their university department and their answers were consequently excluded from the data set. The responses of 99 pre-service teachers were included in the present study. 53 of them (19 male and 34 female) were preparing to be history teachers; 46 of them ( 25 male and 22 female) intended to be mathematics teachers.

\section{Data Collection Form}

Data was collected from pre-service teachers who were students in the faculty of education at Eskişehir Osmangazi University in Turkey. Data was obtained over a one hour class session in the end of the semester. First of all, the aims of the present study were explained to all students, thereafter students were invited to complete an individual form that includes questions. As pre-service teachers raised some questions, explanations were made to them.

Data was obtained from each participant using a form that includes demographic information such as age, gender, and department, and also includes written questions. For each question there were two pages. The first page included the purpose of the research, demographic information, and directions. The next page of the form was divided into two halves for each one of the research questions, stated as follows.

Two open-ended questions were asked from participants after they completed their school experiences: 
1. What factors facilitated your school-based learning during your in-school experiences?

2. In general, what features should schools have in order to make your school-based learning better?

The data was collected in Turkish and then translated into English. The participants were expected to write at least one sentence. For credibility of the data collection form, expert opinions from two experts were taken into account, one specialized in educational administration and one specialized in counseling.

\section{Findings}

\section{Findings for Motivational Factors that Influence Pre-service Teachers' School- based Learning during their Experiences in the School}

The responses to the study questions were progressively analyzed using a sentencebased content analysis method. Initially, emergent themes were used. For instance, for each one of the theme, one sample sentence was provided. For the first question, participants claimed "school had a positive atmosphere" and "school was a good place for me" as significant statements. Then, researchers came up with the theme "positive school climate." In addition, participants stated "the school manager had a supportive manner" and "the school manager did not force us and helped us." Studies in the literature indicated that a positive school climate is a general concept that aims to capture the atmosphere of a school. Individuals experience the school climate and it describes their collective perceptions of routine behavior. Moreover, it affects their attitudes and behavior in the school (Freiberg \& Stein, 1999; Hoy, Tarter, \& Bliss, 1990). Therefore, researchers came up with an exhaustive description of "positive school structure" based on these significant sentences and related literature.

The same procedure was used for the rest of data. In the beginning, significant statements were determined. These statements were then grouped into themes. The themes in turn were integrated into exhaustive descriptions. The researchers used the related literature to identify themes and exhaustive descriptions. For example, current literature and theoretical explanations were used to name categories and subcategories in the present study. For instance: Social structural and cultural aspects, social interaction and relationship, students' engagement and motivation (Pintrich \& Schunk, 2002), class atmosphere (Ames, 1992), teachers' sense of self-efficacy (Bandura, 1986), supportive learning environment (Dembo \& Gibson, 1985), democratic education (Flores, 2001), autonomy (Ronfeldt et al., 2013) collaboration process in professional development schools (Rice, 2002), school climate (Cohen \& Michelli, 2006), supervisor quality (Ronfeldt et al., 2013) teacher qualities (Stronge, 
2007), culture and school structure (Teitel, 2001), and guide and competence of mentors (Grossman \& Thompson, 2004) were considered in some aspects.

After integrating the exhaustive descriptions, the researchers independently went back to the paragraphs to discover the relationships among the exhaustive descriptions.

\begin{tabular}{|c|c|c|}
\hline \multicolumn{3}{|c|}{$\begin{array}{l}\text { Table } 1 \\
\text { Motivational Factors that Influence Pre-service Teachers'School-based Learning during their Experiences } \\
\text { in the School }\end{array}$} \\
\hline $\begin{array}{l}\text { Exhaustive } \\
\text { descriptions }\end{array}$ & Themes & Significant statements \\
\hline \multirow{2}{*}{$\begin{array}{l}\text { Positive school } \\
\text { structure }\end{array}$} & Positive school climate & $\begin{array}{l}\text { School was a good place for me. } \\
\text { School had a positive atmosphere. }\end{array}$ \\
\hline & $\begin{array}{l}\text { Management's positive } \\
\text { attitudes }\end{array}$ & $\begin{array}{l}\text { The school manager had a supportive manner. } \\
\text { The school manager did not force and helped us. }\end{array}$ \\
\hline \multirow{4}{*}{$\begin{array}{l}\text { Qualities of } \\
\text { other teachers in } \\
\text { the school }\end{array}$} & $\begin{array}{l}\text { Positive attitudes towards } \\
\text { pre-service teacher }\end{array}$ & $\begin{array}{l}\text { Other teachers showed positive attitudes towards us. } \\
\text { Thanks to their positive attitudes towards us, I learnt new things. }\end{array}$ \\
\hline & Social support & $\begin{array}{l}\text { They dealt with us. } \\
\text { They really cared about our work. }\end{array}$ \\
\hline & Competence & $\begin{array}{l}\text { Thanks to skilled teachers, I learnt new things. } \\
\text { They were competent teachers. Thus, I learnt new things. }\end{array}$ \\
\hline & Personality traits & $\begin{array}{l}\text { I had learnt many new things since they were agreeable persons. } \\
\text { Other teachers were affectionate. }\end{array}$ \\
\hline \multirow{2}{*}{$\begin{array}{l}\text { Qualities of } \\
\text { class in the } \\
\text { school }\end{array}$} & $\begin{array}{l}\text { Having good physical } \\
\text { structure }\end{array}$ & $\begin{array}{l}\text { Classroom was comfortable for learning. } \\
\text { Classrooms had enough light and temperature. }\end{array}$ \\
\hline & $\begin{array}{l}\text { Equipped with } \\
\text { instructional materials. }\end{array}$ & $\begin{array}{l}\text { There were different instructional materials in the class. } \\
\text { Classrooms were equipped with several kinds of instructional } \\
\text { materials. }\end{array}$ \\
\hline \multirow{3}{*}{$\begin{array}{l}\text { Qualities of } \\
\text { students in the } \\
\text { school }\end{array}$} & $\begin{array}{l}\text { High level of motivation } \\
\text { and to learn }\end{array}$ & $\begin{array}{l}\text { Students had high levels of curiosity and engagement. } \\
\text { Students displayed much interest for lessons. }\end{array}$ \\
\hline & Personality traits & $\begin{array}{l}\text { Students were thoughtful. } \\
\text { Students did not have much anxiety. }\end{array}$ \\
\hline & $\begin{array}{l}\text { Establishing positive } \\
\text { relationships }\end{array}$ & $\begin{array}{l}\text { Students displayed respect towards us. } \\
\text { Students established positive communication with us. }\end{array}$ \\
\hline \multirow{4}{*}{$\begin{array}{l}\text { Qualities of pre- } \\
\text { service teachers }\end{array}$} & $\begin{array}{l}\text { High level of motivation } \\
\text { to be teacher }\end{array}$ & $\begin{array}{l}\text { I was highly eager to learn. } \\
\text { I did not lose my teaching excitement. }\end{array}$ \\
\hline & Ability and interest & $\begin{array}{l}\text { I have the ability to teaching history/mathematics. } \\
\text { I have an interest to teaching history/mathematics. }\end{array}$ \\
\hline & Prepare for teaching & $\begin{array}{l}\text { I had already studied the subjects. } \\
\text { I prepared many questions for students before teaching. }\end{array}$ \\
\hline & $\begin{array}{l}\text { Using different teaching } \\
\text { method }\end{array}$ & $\begin{array}{l}\text { I had used different teaching methods such as group working, } \\
\text { cooperative learning, and project based learning. } \\
\text { In addition to lecturing, } 1 \text { carried out different teaching methods. }\end{array}$ \\
\hline \multirow{5}{*}{$\begin{array}{l}\text { Qualities of } \\
\text { mentors }\end{array}$} & $\begin{array}{l}\text { Positive attitudes towards } \\
\text { pre-service teacher }\end{array}$ & $\begin{array}{l}\text { The mentor exhibited positive behavior toward us. } \\
\text { The mentor had positive attitudes toward us. . }\end{array}$ \\
\hline & Social support & $\begin{array}{l}\text { The mentor provided great convenience to us. } \\
\text { They motivated us. }\end{array}$ \\
\hline & Competence & $\begin{array}{l}\text { The mentor was competent teacher. } \\
\text { The mentor had given true guidance. Thus, I learned new things. }\end{array}$ \\
\hline & Personality traits & $\begin{array}{l}\text { The mentor had an optimistic point of view. } \\
\text { The mentor was affectionate. }\end{array}$ \\
\hline & $\begin{array}{l}\text { Establishing positive } \\
\text { relationships }\end{array}$ & $\begin{array}{l}\text { The mentor had established a positive relationship with me. } \\
\text { The mentor was accordant with me. }\end{array}$ \\
\hline
\end{tabular}


Then, they found relationships among the exhaustive descriptions. They constructed relationships among the exhaustive descriptions and graphical representations as initial models. Researchers read the paragraphs related to exhaustive descriptions, and also a second time they came together in order to determine the relationships of the two models. The two researchers compared model dimensions to reconcile the differences that emerged in the initial analysis.

Overall, there might be many aspects to the motivational factors for school-based teacher learning. Analyses of pre-service teachers' written responses indicated six main motivational factors that increase their school-based learning. The results of these analyses may be found in Table 1.

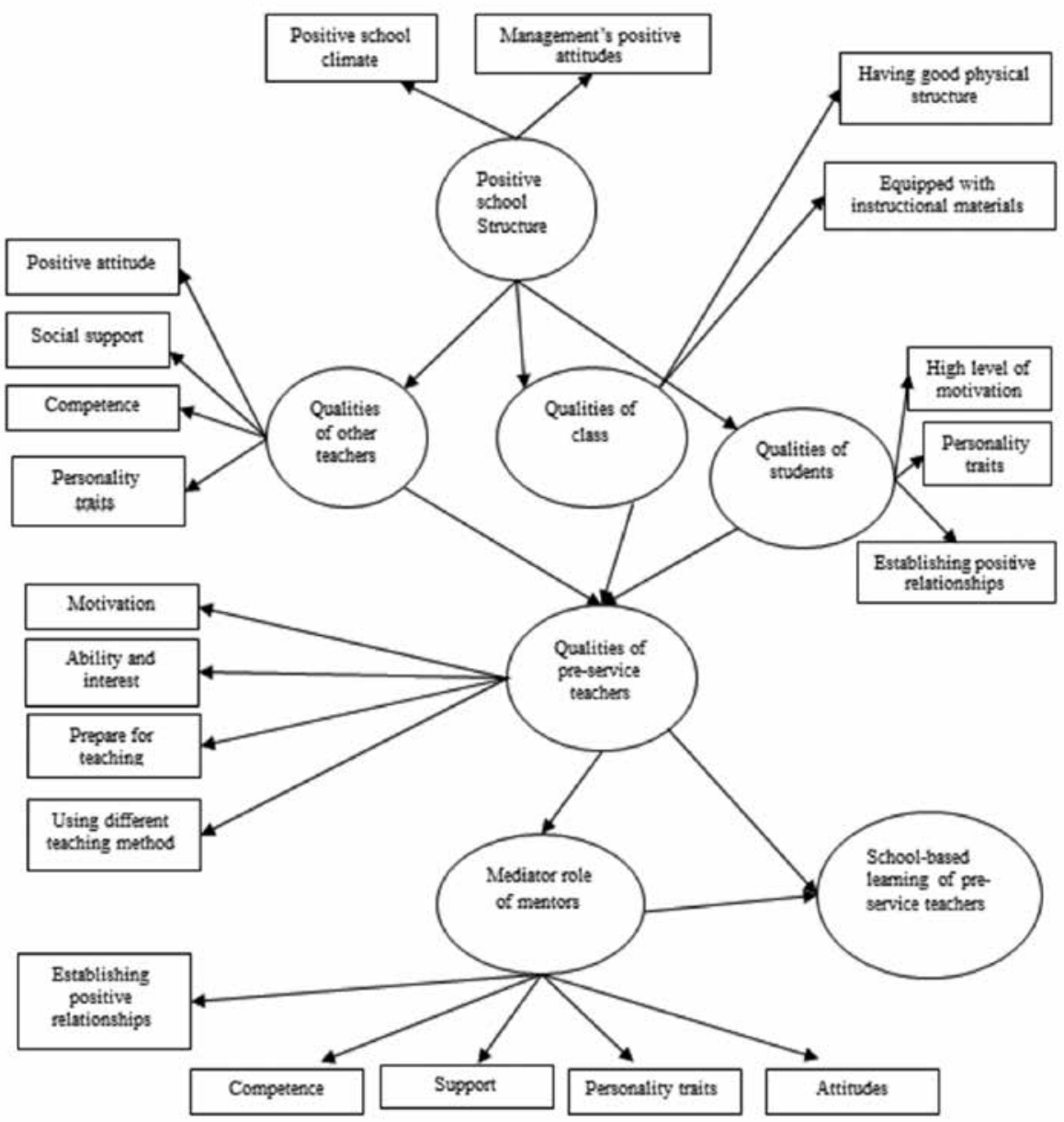

Figure 1. Theoretically and empirically supported model for motivational factors related to pre-service teachers' experiences from school-based learning. 
The motivational exhaustive descriptions and themes enabled the researchers to derive a theoretically and empirically supported model. Data exemplars were selected in order to depict the exhaustive descriptions and their relationships within the final model. The theoretically and empirically supported model is shown in Figure 1.

According to the model (Figure 1), positive school structure is related to qualities of teachers, classrooms and students. These are related to pre-service school teachers' qualities. Additionally, there was a mediator role of mentors between qualities of pre-service school teachers and their school-based learning. Researchers reached these relationships based on their reading of paragraphs in the data. Examples of these paragraphs were:

You get experience, you teach... As you do it again and again, you discover new things. The school administration was the main factor facilitating learning new things. When they provide order, create a positive atmosphere in school and sustain it, teaching in classes become consistent. Students' interest in classes and our enthusiasm and willingness to learn... Factors such as teacher attitudes paved the way for us to learn new things. We felt positive influence. Positive interaction between teachers and students was important. The most important of all was our supervisor, he facilitated all these and reflected our relationships to all in school. (Pre-service teacher, Mathematics)

Based on my observations in school, the learning environment of the school had an effect upon the relationships among teachers, class atmosphere, and students. They also influenced my motivation to teach positively. (Pre-service teacher, History)

Positive qualities of teachers, their competencies, and positive attitudes towards us, along with good physical structure and equipment, students' willingness to learn, and their eagerness to work increased our desire to learn new things in the school. Moreover, our supervisor helped us interact with the school manager, teachers, and students easily and I learned a lot with her support. (Pre-service teacher, Mathematics)

The three examples of paragraphs provided here led the researchers to depict the relationships among exhaustive descriptions as follows: Positive school structure influences the qualities of teachers, classrooms, and students. These exhaustive descriptions in turn positively influence the quality of pre-service teachers. The role of mentors (supervisors) emerged as a mediator for school-based learning.

\section{Findings for Motivational Factors that Influence Pre-service Teachers' School- based Learning with Respect to their Expectations}

Overall, there might be many aspects to the motivational factors for school-based teacher learning. Analyses of pre-service teachers' written responses indicated five main motivational factors that increase their school-based learning with respect to expectations. The results of these analyses may be found in Table 2. 
Table 2

Motivational Factors that Influence Pre-service Teachers' School-based Learning with respect to their Expectations

\begin{tabular}{|c|c|c|}
\hline $\begin{array}{l}\text { Exhaustive } \\
\text { descriptions }\end{array}$ & Themes & Significant statements \\
\hline \multirow{7}{*}{$\begin{array}{l}\text { Positive school } \\
\text { structure }\end{array}$} & Open to innovation & $\begin{array}{l}\text { School should follow the latest developments, for instance } \\
\text { new books should be bought. } \\
\text { School should catch up with the times. }\end{array}$ \\
\hline & Goal setting and striving & $\begin{array}{l}\text { School should have specific goals, and also should strive } \\
\text { for them. } \\
\text { School should have developmental goals. }\end{array}$ \\
\hline & $\begin{array}{l}\text { Implementing activity based } \\
\text { instruction }\end{array}$ & $\begin{array}{l}\text { Scientific activities should be implemented continuously. } \\
\text { Activity-based instruction should be implemented in the } \\
\text { school. }\end{array}$ \\
\hline & $\begin{array}{l}\text { Implementing student } \\
\text { centered learning }\end{array}$ & $\begin{array}{l}\text { Student-based learning should be implemented. } \\
\text { School should value the students' opinion. }\end{array}$ \\
\hline & $\begin{array}{l}\text { Implementing collaborative } \\
\text { education }\end{array}$ & $\begin{array}{l}\text { Students and the teacher should be in cooperation. } \\
\text { Cooperative learning should be implemented. }\end{array}$ \\
\hline & $\begin{array}{l}\text { Implementing democratic } \\
\text { education }\end{array}$ & $\begin{array}{l}\text { Everybody should freely express their opinions and } \\
\text { emotions. } \\
\text { The school atmosphere should be democratically structured. }\end{array}$ \\
\hline & $\begin{array}{l}\text { Positive relationships in } \\
\text { school }\end{array}$ & $\begin{array}{l}\text { Intimate relationships should be established in the school. } \\
\text { Positive relationships should be established between } \\
\text { students, teachers, and school managers. }\end{array}$ \\
\hline \multirow{3}{*}{$\begin{array}{l}\text { Qualities of other } \\
\text { teachers in the } \\
\text { school }\end{array}$} & Open to cooperation & $\begin{array}{l}\text { Other teachers should be in cooperation. } \\
\text { Other teachers should correspond with other teachers and } \\
\text { students. }\end{array}$ \\
\hline & High level of motivation & $\begin{array}{l}\text { Teachers should believe in developing students. } \\
\text { Teachers should have a high enthusiasm to teach. }\end{array}$ \\
\hline & $\begin{array}{l}\text { High professional } \\
\text { competence }\end{array}$ & $\begin{array}{l}\text { Teachers should be competent. } \\
\text { Skilled teachers should be in the school. }\end{array}$ \\
\hline \multirow{3}{*}{$\begin{array}{l}\text { Qualities of class } \\
\text { in the school }\end{array}$} & $\begin{array}{l}\text { Having good physical } \\
\text { structure }\end{array}$ & $\begin{array}{l}\text { School should be clean and well-lit. } \\
\text { School should be noise free. }\end{array}$ \\
\hline & $\begin{array}{l}\text { Equipped with instructional } \\
\text { materials. }\end{array}$ & $\begin{array}{l}\text { There should be different instructional materials in the class. } \\
\text { Classrooms should be equipped with several kinds of } \\
\text { instructional materials }\end{array}$ \\
\hline & Small class size & $\begin{array}{l}\text { Class size should be small. } \\
\text { Classroom should not be very crowded. }\end{array}$ \\
\hline \multirow{2}{*}{$\begin{array}{l}\text { Qualities of } \\
\text { students in the } \\
\text { school }\end{array}$} & $\begin{array}{l}\text { High level of motivation and } \\
\text { to learn }\end{array}$ & $\begin{array}{l}\text { Students should have high levels of eagerness to learn. } \\
\text { Students should be highly active to learn. }\end{array}$ \\
\hline & High level of self-regulation & $\begin{array}{l}\text { Students should not disrupt the positive class atmosphere. } \\
\text { Students should have a high level of self-regulation. }\end{array}$ \\
\hline
\end{tabular}

The motivational exhaustive descriptions and themes enabled the researchers to derive a theoretically and empirically supported model with respect to pre-service student expectations. Data exemplars were selected in order to depict the exhaustive descriptions and their relationships within the final model. The theoretically and empirically supported model is provided in Figure 2. 


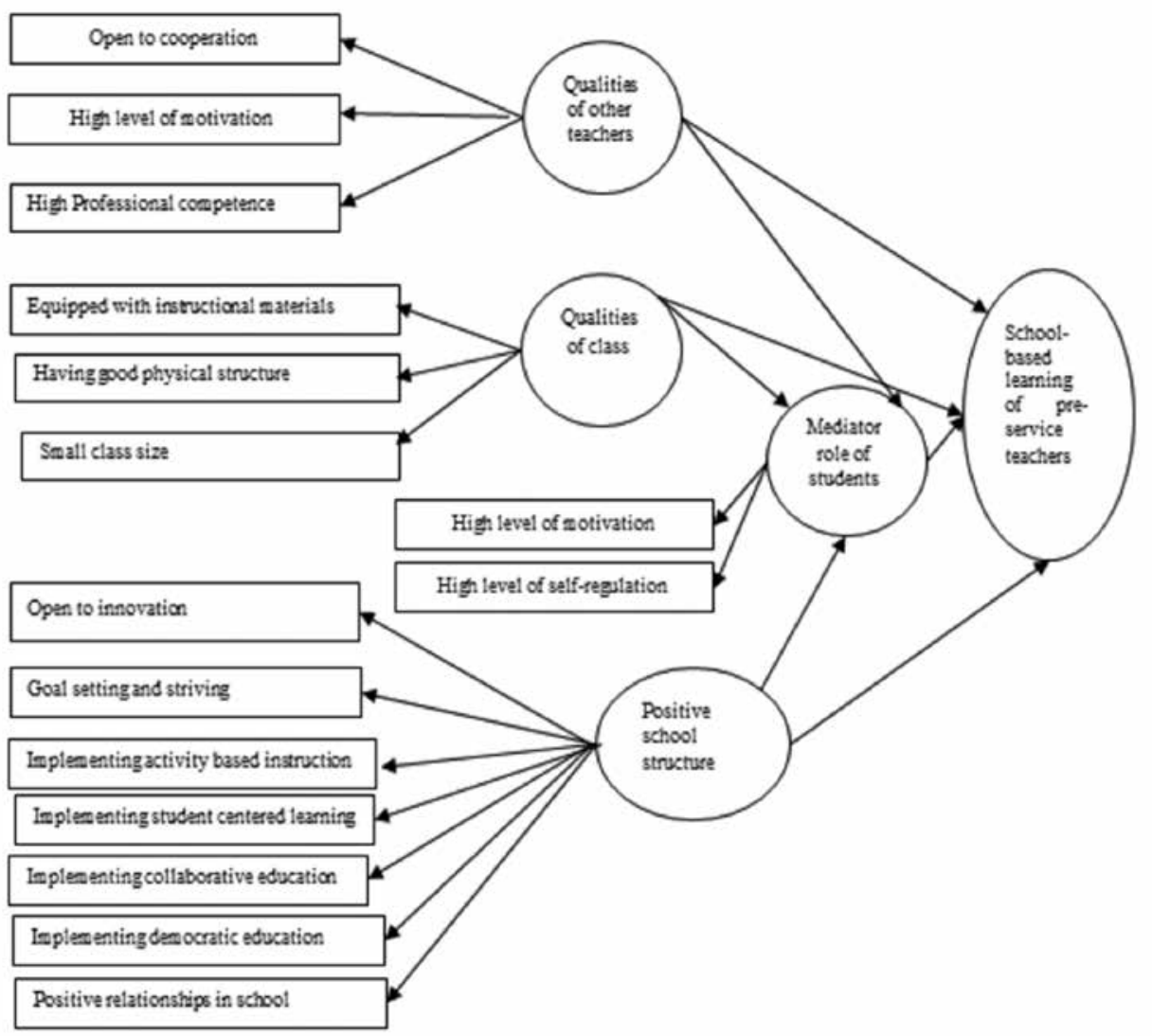

Figure 2. Theoretically and empirically supported model for motivational factors related to pre-service teachers' expectations from school-based learning.

Researchers reached these relationships based on their reading of paragraphs in the data. Examples of these paragraphs were:

For me if I learn new things, school has to have some qualities. First of all, teachers should interact with another. Moreover, the classroom should not be crowded and needs to be comfortably spacious. Democratic, comfortable, and free learning environment facilitates learning new things. The school administration and teachers should cooperate. Students who were willing and open to learn are the most important factor since they are related to all. (Pre-service teacher, Mathematics)

When teachers are competent and willing to teach, when the classroom is equipped with teaching materials, is clean, and has order, I will learn new things. Also, school should have an innovative and student-centered teaching approach. When school has some goals, a competent administration and teachers will help me to try and learn new things. Overall, when students have a certain level for learning, they will force me, administrators and teachers to try new things and thus I will likely be motivated and learn new things. (Pre-service teacher, History) 
The two examples of paragraphs provided in this section led the researchers to depict the relationships among exhaustive descriptions as follows: Qualities of teachers, classrooms, positive school structure, and students. These exhaustive descriptions in turn positively influence pre-service teachers' school-based learning. Here, the role of students emerged as mediator for school-based learning.

\section{Discussion}

Pre-service teacher experiences about motivational factors for school-based teacher learning were investigated. In literature, the subject of motivation to learn for teachers has been generally investigated from the perspectives of school development and professional development (Hoekstra \& Korthagen, 2011). Furthermore, studies emphasize that motivational factors are necessary for teachers' learning (Borko \& Putnam, 1996). This study specifically investigated the subject in terms of the motivational factors that were important for school-based teacher learning. More specifically, this study considered teacher experiences and expectations. Motivational factors were found to differ for pre-service teachers regarding their experiences and expectations. While pre-service teacher views on school-related motivational factors are more general than their expectations, their experiences emphasized more specific factors. These results might be considered ideal and real perspectives.

The study found a variety of motivational components for pre-service teacher school-based learning such as school, mentors, students, classrooms, other teachers, educational approaches, and intimate relationships. These findings suggest that a holistic practice-based approach needs to be used for increasing school-based teacher learning. This approach has been previously emphasized by Hollins (2011). The results of this study support the idea that the concept of teaching and learning is a complex and multi-dimensional process (Zeichner, 2009). The findings also suggest that a systematic approach (Burke, 2008) may be used to enhance school-based preservice teacher learning.

The most important finding in this study is that when considering their experiences, pre-service teachers pointed out the importance of pre-service teachers' qualities as a motivational factor; whereas, they did not consider their own qualities as motivational factors in their expectations regarding school-based teacher learning. This difference might be attributed to cultural factors. Every society has a unique educational system, as the social construction of educational realities in a particular society differs from other societies (Pokewitz, 2010). Teacher candidates are selected only according to their academic achievement levels in Turkey. Other factors such as personality traits, abilities, interest, motivational state, and personal relationships are not considered for who should be a teacher. Many teacher candidates may likely to be motivated 
to attain a profession and their motivational states are probably extrinsic. Thus, some participants in this study might have emphasized external motivational factors by excluding themselves. Secondly, they might also have made a basic attribution mistake. When an individual explains the reason for an event, he/she is likely to attribute mistakes to external factors but not him/herself (Lerner \& Miller, 1977). Thus, by perceiving the regulating factors for enhancing the motivation for schoolbased learning to be external only, they did not consider themselves ideally.

The results of this study may also be explained by the expectancy-value theory of motivation. According to this theory, expectations and values are important factors for motivating individuals to make achievement-related choices. Expectations and values influence performance, persistence, and task choice (Eccles \& Wigfield, 2002). When both expectations and experiences were taken into account, an interesting result emerged. While expectancy-value theory emphasizes an individual's competency expectations, the results of this study emphasize both individual competencies (preservice teachers) and school competences. These differences might stem from the differences in cultural and educational systems.

In this study, two holistic models were derived and two significant mediators identified in terms of student and mentor qualities. Mentors' guidance and competence are noted as important factors for pre-service teacher teaching and the learning process (Grossman \& Thompson, 2004). Additionally, student and teacher interactions are also important for a healthy teaching and learning process. If students have higher levels of motivation, this affects teachers' performance (Pintrich \& Schunk, 2002). However, these factors are not considered in a holistic model in previous studies, especially in Turkey. The most important contribution of the present study may be that it produced two holistic models.

According to Schleicher (2011), pre-service teacher views on assessments and feedback have contributed to their development, and therefore contribute to school improvement. Thus, the findings of the present study might be used for professional development of pre-service teachers and school improvement, prevention of teacher attrition, and also the provision of effective teaching and learning environments. They might also guide efforts to implement school-based teacher learning. Moreover, comprehensive models are needed to enhance school-based teacher learning and solve educational problems (Schleicher, 2011). Thus, the model developed using a qualitative research method in the present study might be tested by a quantitative research method, for instance by using structural equations modeling to advance our knowledge of the relationships among those factors.

This study found that motivational factors differed with regards to pre-service teachers' experiences and expectations. Thus, their expectations and experiences 
should be matched in order to enhance their realizations from school-based learning. In addition, the models developed in the current study may be tested quantitatively. Based on results, pre-service teacher' school-based learning experiences may be improved. For instance, teacher education programs may consider taking schoolbased learning as an important part of teacher education. Thus, pre-service teacher motivations may be improved. This may result in schools making more effective utilization of pre-service teachers. The Turkish Ministry of Education recently appointed new teachers as candidate teachers. School-based learning may also contribute to the learning and motivation of these candidates, and schools may also benefit from these candidate teachers.

\section{References}

Ames, C. (1992). Classrooms: Goals, structures, and student motivation. Journal of Educational Psychology, 84, 261-271.

Bandura, A. (1986). Social foundations of thought and action: A social cognitive theory. Englewood Cliffs, NJ: Prentice-Hall.

Borko, H., \& Putnam, R. (1996). Learning to teach. In D. Berliner \& R. Calfee (Eds.), Handbook of educational psychology (pp. 673-708). New York, NY: Macmillan.

Burke, J. (2008). The teacher's essential guide series: Effective instruction. New York, NY: Scholastic Inc.

Canrinus, E. T., \& Fokkens-Bruinsma, M. (2014) Changes in student teachers' motives and the meaning of teacher education programme quality. European Journal of Teacher Education, $37(3), 262-278$.

Chait, R. (2010). Removing chronically ineffective teachers: Barriers and opportunities. Washington, DC: Centre for American Progress.

Christensen, L. B., Johnson, R. B., \& Turner, L. A. (2015). Araştırma yöntemleri desen ve analiz [Research methods: Design and analysis] (Trans. Ed. A. Aypay). Ankara, Turkey: Anı.

Cohen, J., \& Michelli, N. M. (2006). Evaluating school climate: Promoting the skills, dispositions and a climate for democracy. National Network for Educational Renewal News, 6(1), 2-4.

Cuenca, A. (2010). In loco pedagogues: The pedagogy of a novice university supervisor. Studying Teacher Education, 6(1), 29-43.

Daniel, P. L., \& Stallion, B.K. (1996). Implementing school-based professional development in Kentucky. Journal of Staff Development, 17(4), 30-32.

Davey, R. (2013). The professional identity of teacher educators: Career on the cusp? London, England: Routledge.

Deci, E. L., \& Ryan, R. M. (1985). Intrinsic motivation and self-determination in human behavior. New York, NY: Plenum.

Dembo, M., \& Gibson, S. (1985). Teachers' sense of efficacy: An important factor in school improvement. The Elementary School Journal, 86(2), 173-184.

Eccles, J. S., \& Wigfield, A. (2002). Motivational beliefs, values and goals. Annual Review of Psychology, 53, 109-141. 
Freiberg, H. J., \& Stein, T. A. (1999). Measuring, improving, and sustaining healthy learning environments. In H. J. Freiberg (Ed.), School climate: Measuring, improving, and sustaining healthy learning environments (pp. 11-29). London, UK: Falmer Press.

Flores, M. A. (2001). Person and context in becoming a new teacher. Journal of Education for Teaching, 27(2), 135-148.

Fokkens-Bruinsma, M., \& Canrinus, E. T. (2011). Wat motiveerde je om docent te worden? Relaties met professionele betrokkenheid en vertrouwen in eigen kunnen bij beginnende en ervaren docenten [What motivated you to become a teacher? Relationships with professional commitment and self-efficacy of beginning and experienced teachers]. Pedagogische Studiën, 88, 41-56.

Creswell, J. W. (2007). Qualitative inquiry and research design. London, UK: Sage.

Fraenkel, J. R., \& Wallen, N. E. (1993). How to design and evaluate research in education. New York, NY: Mcgraw Hill.

Grootenboer, P. (2005). The impact of the school-based practicum on pre-service teachers' affective development in mathematics. Mathematics Teacher Education and Development, 7, 18-32.

Grossman, P., \& Thompson, C. (2004). District policy and beginning teachers: A lens on teacher learning. Educational Evaluation and Policy Analysis, 26(4), 281-301.

Hollins, E. R. (2011). Teacher preparation for quality teaching. Journal of Teacher Education, $62(4), 395-407$.

Hoy, W. K., Tarter, C. J., \& Bliss, J. R. (1990). Organizational climate, school health, and effectiveness: A comparative analysis. Educational Administrative Quarterly, 26(3), 260-279.

Hoekstra, A., \& Korthagen. F. A. J. (2011). Teacher learning in a context of educational change: Informal learning versus systematic support. Journal of Teacher Education, 62(1), 76-92.

Hudson, P. (2010). School-based experiences: Developing primary science preservice teachers' practices. Journal of Science and Mathematics in Southeast Asia, 33(2), 149-167.

Hudson, P., \& Hudson, S. (2012). Examining preservice teachers' applied learning experiences in the Teacher Education Done Differently (TEDD) project. Teacher Education and Practice, 25(3), 421-440.

Kline, R. B. (2005). Principles and practice of structural equation modeling (2nd ed.). New York, NY: Guilford.

Korthagen, F., Loughran, J., \& Russell, T. (2006). Developing fundamental principles for teacher education programs and practices. Teaching and Teacher Education, 22(8), 1020-1041.

Kwakman, K. (2003). Factor's affecting teachers' participation in professional learning activities. Teaching and Teacher Education, 19, 149-170.

Lerner, M. J., \& Miller, D. T. (1978). Just world research and the attribution process: Looking back and ahead. Psychological Bulletin, 85, 1030-1051.

Okpala, C. O., \& Ellis, R. (2005). The perceptions of students on teacher quality: A focus on teacher qualification. Education, 126, 274-283.

Pintrich, P. R., \& Schunk, D. H. (2002). Motivation in education: Theory, research, and applications (2nd ed.). Upper Saddle River, NJ: Merrill Prentice Hall.

Popkewitz, T. (2010). The limits of teacher education reforms: School subjects, alchemies, and an alternative possibility. Journal of Teacher Education 61(5), 413-421.

Powell-Reeve, J. (1992). Understanding motivation and emotion. Orlando: Harcourt Brace Jovanovich College Publishers. 
Rice, E. H. (2002). The collaboration process in professional development schools: Results of a meta-ethnography, 1990-1998. Journal of Teacher Education, 53(1), 55-67.

Roness, D., \& Smith, K. (2010). Stability in motivation during teacher education. Journal of Education for Teaching, 36(2), 169-185.

Ronfeldt, M., Reininger, M., \& Kwok, A. (2013). Recruitment or preparation? Investigating the effects of teacher characteristics and student teaching. Journal of Teacher Education, 64(4), 319-336.

Schleicher, A. (2011). Lessons from the world on effective teaching and learning environments. Journal of Teacher Education, 62(2), 202-221.

Simsek, H., \& Yildirim, A. (2001). The reform of pre-service teacher education in Turkey. In G. R. Sultana (Ed.), Challenge and change in the Euro-Mediterranean region: Case studies in educational innovation (pp. 411-432). New York, NY: Peter Lang.

Stronge, J. H. (2007). Qualities of effective teachers (2nd ed.). Alexandria, VA: ASCD.

Teitel, L. (2001). An assessment framework for professional development schools: Going beyond the leap of faith. Journal of Teacher Education, 52, 57-69.

Trigwell, K., \& Prosser, M. (1996). Changing approaches to teaching: A relational perspective. Studies in Higher Education, 21, 275-284.

Turner, J. C., \& Patrick, H. (2004). Motivational influences on student participation in classroom learning activities. Teachers College Record, 106, 1759-1785.

Uygun, S., \& Akıncı, M. (2015). Comparison of "school experience" and "teaching practice" activities in teacher training systems of turkey and England. Procedia - Social and Behavioral Sciences, 186, 216-221.

Williams, J. (2014). Teacher educator professional learning in the third space: implications for identity and practice. Journal of Teacher Education, 65(4), 315-326.

Zeichner, K. (2009) Teacher education and the struggle for social justice. New York, NY: Routledge. 
